Journal Club

Editor's Note: These short reviews of recent JNeurosci articles, written exclusively by students or postdoctoral fellows, summarize the important findings of the paper and provide additional insight and commentary. If the authors of the highlighted article have written a response to the Journal Club, the response can be found by viewing the Journal Club at www.jneurosci.org. For more information on the format, review process, and purpose of Journal Club articles, please see http://jneurosci.org/content/ preparing-manuscript\#journalclub.

\title{
Remote Control: Impacts of Peripheral Tumor Necrosis Factor-Alpha on Alzheimer Disease-Related Pathology
}

\author{
Patrick Süß \\ Institute of Neuropathology, Faculty of Medicine, University of Freiburg, 79106 Freiburg, Germany \\ Review of Paouri et al.
}

The role of inflammatory mechanisms in the pathogenesis of Alzheimer disease (AD) is increasingly being recognized. Genome-wide association studies have identified several single nucleotide polymorphisms in immune-related genes as risk factors for AD development (Naj et al., 2011). AD pathology is modulated not only by activation of microglia and increases in cytokines like tumor necrosis factor- $\alpha$ (TNF- $\alpha$ ) in the brain (Wyss-Coray and Rogers, 2012; Heneka et al., 2015), but also by components of the peripheral immune system. In fact, peripheral monocytederived cells were suggested to be more capable of clearing $\beta$-amyloid $(\mathrm{A} \beta$ ) plaques than resident microglia (Simard et al., 2006). However, peripheral immune cells are not recruited to the brain in $\mathrm{AD}$ mouse models without further interventions, such as head irradiation (Prinz and Priller, 2017). Peripheral inflammation might also enable monocytes to infiltrate the brain in AD. Indeed, inhibition of the immune checkpoint protein programmed death-1, a negative regulator of inflammation, was reported to induce systemic inflammation mediated by interferon-gamma (Baruch et al., 2016), and this led to brain invasion

Received May 29, 2017; revised July 21, 2017; accepted July 25, 2017. The authors declare no competing financial interests. Correspondence should be addressed to Patrick Süß, University of Freiburg, Faculty of Medicine, Institute of Neuropathology, Breisacher Straße 64, 79106 Freiburg, Germany. E-mail: Patrick.suess@uniklinik-freiburg.de. DOI:10.1523/JNEUROSCI.1480-17.2017

Copyright $\odot 2017$ the authors $\quad 0270-6474 / 17 / 378045-03 \$ 15.00 / 0$ of monocyte-derived macrophages accompanied by increased $\mathrm{A} \beta$ clearance and improved memory in mice carrying five mutations causing familial AD (5XFAD mice; Baruch et al., 2016).

To investigate the influence of chronic peripheral inflammation on AD pathology, several studies have combined mouse models of rheumatoid arthritis (RA) with models of neurodegeneration. These approaches have produced considerably variable effects on neuropathology, depending on the particular kind of peripheral inflammation. Collagen-induced arthritis induced monocyte infiltration and reduced tau deposition in the brains of tau transgenic mice (Lang et al., 2017), and it decreased amyloid plaque load in APP/PS1 mice (Park et al., 2011). In contrast, osteoarthritis triggered by interleukin- $1 \beta$ expression exacerbated plaque load in APP/PS1 mice (Kyrkanides et al., 2011). Despite the involvement of TNF- $\alpha$ in the pathogenesis of both RA and $\mathrm{AD}$, the role of peripheral TNF- $\alpha$ in the interplay of chronic peripheral inflammation and neurodegeneration has not yet been thoroughly investigated. Of note, RA patients receiving anti-TNF- $\alpha$ therapy have a reduced risk of developing AD in later life (Chou et al., 2016).

In a study recently published in The Journal of Neuroscience, Paouri et al. (2017) demonstrated differing effects of peripheral human TNF- $\alpha$ expression on amyloid plaque load, glial activation, and synaptic integrity in the brain of 5XFAD mice. The authors crossed 5XFAD mice (Oakley et al., 2006) with Tg197 mice, which express human TNF- $\alpha$ modified in its $3^{\prime}$-untranslated region to yield constitutive overexpression and serve as a model of RA (Keffer et al., 1991). They found that 5XFAD/Tg197 (5XTg197) mice had reduced amyloid deposition in the hippocampus and cortex compared with 5XFAD controls at the ages of 2.5 and 4 months (Paouri et al., 2017, their Figs. 1, 2). Inhibition of human TNF- $\alpha$ with the monoclonal antibody infliximab had no effect on plaque load in 5XFAD mice, but partially restored $A \beta$ deposition in 5XTg197 mice (Paouri et al., 2017, their Figs. 1, 2). Expression of human TNF- $\alpha$ also promoted microglial activation in mice. Although several plaque-associated Iba ${ }^{+}$ microglia with morphological signs of activation were detected in the cortex of 5XFAD mice, 5XTg197 mice showed a diffuse and pronounced increase in Ibal immunoreactivity, which was reversed by infliximab treatment (Paouri et al., 2017, their Fig. 4A). Interestingly, Tg197 mice also had diffuse cortical microgliosis at the age of 1 month, when infliximab treatment of 5XTg197 mice was initiated (Paouri et al., 2017, their Fig. 5C). This suggests that infliximab treatment not only prevented the activation of microglia, but also rescued pre-existing gliosis.

Compared with in the serum, the levels of human TNF- $\alpha$ were low in the brain of 5XTg197 mice, and they might have been 
restricted to small blood residues within brain homogenates. Moreover, brain levels of human TNF- $\alpha$, unlike serum levels, were not reduced by infliximab treatment (Paouri et al., 2017, their Fig. 6A,B). These observations, together with the findings that neither infliximab (Paouri et al., 2017, their Fig. 6C,D) nor human TNF- $\alpha$ itself (Banks et al., 1998) cross the murine blood-brain barrier, led the authors to attribute the observed effects on $A \beta$ pathology and glial response in 5XTg197 mice to peripheral human TNF- $\alpha$.

To dissect the roles of microglia and blood-derived leukocytes in the modulation of amyloid pathology and glial activation in 5XTg197 mice, Paouri et al. (2017) performed immunofluorescence analyses using various leukocyte and myeloid cell markers. In the cortex and corpus callosum, there was increased immunoreactivity for CD45 in ramified parenchymal microglia as well as in what were most likely infiltrating CD $45^{+}$leukocytes in the parenchyma and in association with blood vessels (Paouri et al., 2017, their Fig. 8AC). The density of all CD $45^{+}$cells in the brain was increased in Tg197 mice and even further augmented in 5XTg197 mice. Infliximab treatment reduced $\mathrm{CD} 45^{+}$cell density in 5XTg197 mice (Paouri et al., 2017, their Fig. 8D). Further characterization of immune cell populations showed recruitment of $\mathrm{Ly}_{6 \mathrm{C}}{ }^{+}$monocytes in the cerebral vasculature of Tg197 and 5XTg197 mice (Paouri et al., 2017, their Fig. 9A,B). Staining for the recently discovered microglial marker TMEM119 (Bennett et al., 2016), which distinguishes resident microglia from infiltrating monocyte-derived macrophages, revealed that TMEM119 $\mathrm{CD}^{+} 8^{+}$phagocytic microglia were grouped around amyloid depositions in 5XFAD mice and in 5XTg197 mice treated with infliximab. In contrast, $\mathrm{CD}{ }^{+}$phagocytes in the brains of Tg197 and 5XTg197 mice were predominantly TMEM119 ${ }^{-}$, suggesting that these cells were monocytederived (Paouri et al., 2017, their Fig. 9C). Infliximab treatment significantly reduced the recruitment of Ly6C ${ }^{+}$cells and TMEM119 ${ }^{-}$cells in 5XTg197 mice (Paouri et al., 2017, their Fig. 9A-C). These data show that peripheral human TNF- $\alpha$ can direct $\mathrm{CD}_{4}{ }^{+}$leukocytes, including $\mathrm{Ly}_{6 \mathrm{C}}{ }^{+}$ monocytes and TMEM $119^{-} \mathrm{CD}^{+} 8^{+}$monocyte-derived phagocytes, to the brain vasculature and parenchyma and affect the phagocytic activation of microglia and infiltrating cells.

Finally, the authors examined the effect of peripheral human TNF- $\alpha$ on neuronal integrity in 5XTg197 mice. Intensity of staining for the synaptic vesicle protein synaptophysin was reduced in the cortex of Tg197 and 5XTg197 mice and restored by infliximab treatment (Paouri et al., 2017, their Fig. 10 B, D). This suggests that peripheral human TNF- $\alpha$ disrupts synaptic integrity.

In summary, the study by Paouri et al. (2017) identifies peripheral TNF- $\alpha$ as an important modulator of $\mathrm{AD}$ pathology. Whether peripheral TNF- $\alpha$ is primarily beneficial or detrimental in $\mathrm{AD}$ remains unclear, however. Although increased plaque clearance in 5XTg197 mice appears beneficial at first sight, the degradation of $\mathrm{A} \beta$ plaques might lead to the release of the more synaptotoxic $\mathrm{A} \beta$ oligomers (Selkoe and Hardy, 2016), thereby accelerating synaptic loss in 5XTg197 mice. In addition, microglia contribute to synaptic impairment in $\mathrm{AD}$ in a complement-dependent fashion (Hong et al., 2016). Interestingly, Paouri et al. (2017) detect $\mathrm{CD}^{+}{ }^{+}$phagocytic microglia and macrophages in proximity to $\mathrm{A} \beta$ depositions (Paouri et al., 2017, their Fig. 9C). These cells might phagocytose $\mathrm{A} \beta$ or synaptic structures. Future studies will be required to visualize the internalization of these potential phagocytic targets by $\mathrm{CD} 8^{+}$cells in 5XTg197 mice and to elucidate signals downstream of peripheral TNF- $\alpha$ that direct phagocytes to their respective destination.

The findings by Paouri et al. (2017) also shed light on the differential roles of resident microglia and circulatory myeloid cells in the modulation of $\mathrm{AD}$ pathology (Meyer-Luehmann and Prinz, 2015) and they clearly demonstrate that these cell populations can be influenced by peripheral TNF- $\alpha$ or its inhibition. This corroborates previous findings that boosting peripheral inflammation can alleviate $A \beta$ pathology by enabling myeloid cells to infiltrate the brain (Baruch et al., 2016). In addition to myeloid cells, however, Paouri et al. (2017) detect round-shaped CD $45^{+} \mathrm{Iba1}{ }^{-}$leukocytes in the brain parenchyma (Paouri et al., 2017, their Fig. 8B). Based on their morphology and marker expression, these cells could represent lymphocytes. Interestingly, a recent study reported increased $\mathrm{T}$ cell infiltration in the brains of 12month-old 5XFAD mice, and this infiltration, along with improved synaptic long-term potentiation, was reduced by TNF- $\alpha$ inhibition (MacPherson et al., 2017). Although the presence of $T$ cells in the brain parenchyma and their contribution to the pathophysiology of $\mathrm{AD}$ is still controversial, these findings suggest that $\mathrm{T}$ cells might be an additional target of peripheral TNF- $\alpha$ and contribute to the modula- tion of AD-related pathology in 5XTg197 mice.

As Paouri et al. (2017) emphasize, the effects of TNF- $\alpha$ on AD depend on the spatiotemporal activity of TNF- $\alpha$ itself and the signals it induces. Of note, the Tg197 mouse model was recently reported to lack signs of microglia activation in the hippocampus (Süß et al., 2015), whereas Paouri et al. (2017) detect robust gliosis in the cortex (Paouri et al., 2017, their Fig. 5). It is therefore conceivable that peripheral TNF- $\alpha$ differentially affects different brain regions. This is in line with the finding that $\mathrm{A} \beta$ deposition is more effectively reduced in the cortex than in the hippocampus of 5XTg197 mice (Paouri et al., 2017, their Figs. $1 D, E, 2 D, E)$, as this reduction requires local leukocyte recruitment and activation of microglia. These observations call for future studies addressing regional differences in the effects of peripheral inflammation on the brain.

Given that the effects of chronic peripheral expression of human TNF- $\alpha$ on AD pathology in 5XTg197 mice include both reduction of $A \beta$ load and acceleration of synaptic impairment and that these effects might vary across brain areas, it is important to consider the effects of peripheral TNF- $\alpha$ on a behavioral level. Unfortunately, however, the severe inflammation in Tg197 and 5XTg197 mice reduces lifespan to 4 months (Keffer et al., 1991; Paouri et al., 2017). Because an age of 4 months is too young to observe robust behavioral alterations in most mouse models of $\mathrm{AD}$ and cognitive impairment in 5XFAD mice develops at 4-5 months (Oakley et al., 2006), cognitive performance cannot be appropriately compared in 5XTg197 and 5XFAD mice. Due to the reduced life expectancy of 5XTg197 mice, the effects of peripheral TNF- $\alpha$ reported by Paouri et al. (2017) are only applicable to the early phase of AD-related pathology in 5XFAD mice and might differ from effects at later disease stages. To address the role of peripheral TNF- $\alpha$ during further $\mathrm{AD}$ progression and to investigate alterations on the behavioral level, an inducible TNF- $\alpha$ transgenic mouse model as the one described recently (Retser et al., 2013) could be used.

In summary, Paouri et al. (2017) demonstrate that chronic overexpression of peripheral human TNF- $\alpha$ efficiently modulates early $\mathrm{AD}$-related pathology in $5 \mathrm{XFAD}$ mice by activating microglia and recruiting peripheral immune cells into the brain. These effects are accompanied by reduced A $\beta$ load, but they might also accelerate synaptic loss. The prominent and diverse effects 
of peripheral TNF- $\alpha$ and its inhibition on the brain must be evaluated thoroughly in the context of neurodegeneration, as well as in chronic inflammatory diseases like RA.

\section{References}

Banks WA, Kastin AJ, Ehrensing CA (1998) Diurnal uptake of circulating interleukin- $1 \alpha$ by brain, spinal cord, testis and muscle. Neuroimmunomodulation 5:36-41. CrossRef Medline

Baruch K, Deczkowska A, Rosenzweig N, TsitsouKampeli A, Sharif AM, Matcovitch-Natan O, Kertser A, David E, Amit I, Schwartz M (2016) PD-1 immune checkpoint blockade reduces pathology and improves memory in mouse models of Alzheimer's disease. Nat Med 22:135-137. CrossRef Medline

Bennett ML, Bennett FC, Liddelow SA, Ajami B, Zamanian JL, Fernhoff NB, Mulinyawe SB, Bohlen CJ, Adil A, Tucker A, Weissman IL, Chang EF, Li G, Grant GA, Hayden Gephart MG, Barres BA (2016) New tools for studying microglia in the mouse and human CNS. Proc Natl Acad Sci U S A 113:E1738-1746. CrossRef Medline

Chou RC, Kane M, Ghimire S, Gautam S, Gui J (2016) Treatment for rheumatoid arthritis and risk of Alzheimer's disease: a nested casecontrol analysis. CNS Drugs 30:1111-1120. CrossRef Medline

Heneka MT, Carson MJ, El Khoury J, Landreth GE, Brosseron F, Feinstein DL, Jacobs AH, Wyss-Coray T, Vitorica J, Ransohoff RM, Herrup K, Frautschy SA, Finsen B, Brown GC, Verkhratsky A, Yamanaka K, Koistinaho J, Latz E, Halle A, Petzold GC, et al. (2015) Neuroinflammation in Alzheimer's disease. Lancet Neurol 14:388-405. CrossRef Medline

Hong S, Beja-Glasser VF, Nfonoyim BM, Frouin A, Li S, Ramakrishnan S, Merry KM, Shi Q, Rosenthal A, Barres BA, Lemere CA, Selkoe DJ, Stevens B (2016) Complement and microglia mediate early synapse loss in Alzheimer mouse models. Science 352:712-716. CrossRef Medline

Keffer J, Probert L, Cazlaris H, Georgopoulos S,
Kaslaris E, Kioussis D, Kollias G (1991) Transgenic mice expressing human tumour necrosis factor: a predictive genetic model of arthritis. EMBO J 10:4025-4031. Medline

Kyrkanides S, Tallents RH, Miller JN, Olschowka ME, Johnson R, Yang M, Olschowka JA, Brouxhon SM, O'Banion MK (2011) Osteoarthritis accelerates and exacerbates Alzheimer's disease pathology in mice. J Neuroinflammation 8:112. CrossRef Medline

Lang SC, Harre U, Purohit P, Dietel K, Kienhöfer D, Hahn J, Baum W, Herrmann M, Schett G, Mielenz D (2017) Neurodegeneration enhances the development of arthritis. J Immunol 198:2394-2402. CrossRef Medline

MacPherson KP, Sompol P, Kannarkat GT, Chang J, Sniffen L, Wildner ME, Norris CM, Tansey MG (2017) Peripheral administration of the soluble TNF inhibitor XPro1595 modifies brain immune cell profiles, decreases beta-amyloid plaque load, and rescues impaired long-term potentiation in 5xFAD mice. Neurobiol Dis 102:81-95. CrossRef Medline

Meyer-Luehmann M, Prinz M (2015) Myeloid cells in Alzheimer's disease: culprits, victims or innocent bystanders? Trends Neurosci 38: 659-668. CrossRef Medline

Naj AC, Jun G, Beecham GW, Wang LS, Vardarajan BN, Buros J, Gallins PJ, Buxbaum JD, Jarvik GP, Crane PK, Larson EB, Bird TD, Boeve BF, Graff-Radford NR, De Jager PL, Evans D, Schneider JA, Carrasquillo MM, ErtekinTaner N, Younkin SG, et al. (2011) Common variants at MS4A4/MS4A6E, CD2AP, CD33 and EPHA1 are associated with lateonset Alzheimer's disease. Nat Genet 43:436441. CrossRef Medline

Oakley H, Cole SL, Logan S, Maus E, Shao P, Craft J, Guillozet-Bongaarts A, Ohno M, Disterhoft J, Van Eldik L, Berry R, Vassar R (2006) Intraneuronal $\beta$-amyloid aggregates, neurodegeneration, and neuron loss in transgenic mice with five familial Alzheimer's disease mutations: potential factors in amyloid plaque formation. J Neurosci 26:10129-10140. CrossRef Medline
Paouri E, Tzara O, Kartalou GI, Zenelak S, Georgopoulos S (2017) Peripheral tumor necrosis factor-alpha (TNF- $\alpha$ ) modulates amyloid pathology by regulating blood-derived immune cells and glial response in the brain of AD/TNF transgenic mice. J Neurosci 37:51555171. CrossRef Medline

Park SM, Shin JH, Moon GJ, Cho SI, Lee YB, Gwag BJ (2011) Effects of collagen-induced rheumatoid arthritis on amyloidosis and microvascular pathology in APP/PS1 mice. BMC Neurosci 12:106. CrossRef Medline

Prinz M, Priller J (2017) The role of peripheral immune cells in the CNS in steady state and disease. Nat Neurosci 20:136-144. CrossRef Medline

Retser E, Schied T, Skryabin BV, Vogl T, Kanczler JM, Hamann N, Niehoff A, Hermann S, Eisenblätter M, Wachsmuth L, Pap T, van Lent PL, Loser K, Roth J, Zaucke F, Ludwig S, Wixler V (2013) Doxycycline-induced expression of transgenic human tumor necrosis factor $\alpha$ in adult mice results in psoriasis-like arthritis. Arthritis Rheum 65:2290-2300. CrossRef Medline

Selkoe DJ, Hardy J (2016) The amyloid hypothesis of Alzheimer's disease at 25 years. EMBO Mol Med 8:595-608. CrossRef Medline

Simard AR, Soulet D, Gowing G, Julien JP, Rivest S (2006) Bone marrow-derived microglia play a critical role in restricting senile plaque formation in Alzheimer's disease. Neuron 49:489502. CrossRef Medline

Süß P, Kalinichenko L, Baum W, Reichel M, Kornhuber J, Loskarn S, Ettle B, Distler JH, Schett G, Winkler J, Müller CP, Schlachetzki JC (2015) Hippocampal structure and function are maintained despite severe innate peripheral inflammation. Brain Behav Immun 49:156-170. CrossRef Medline

Wyss-Coray T, Rogers J (2012) Inflammation in Alzheimer disease-a brief review of the basic science and clinical literature. Cold Spring Harb Perspect Med 2:a006346. CrossRef Medline 